Chicago-Kent College of Law

Scholarly Commons @ IIT Chicago-Kent College of Law

All Faculty Scholarship

Faculty Scholarship

January 2008

\title{
China - Measures Affecting Imports of Automobile Parts
}

Sungjoon Cho

IIT Chicago-Kent College of Law, scho1@kentlaw.iit.edu

Follow this and additional works at: https://scholarship.kentlaw.iit.edu/fac_schol

Part of the International Trade Law Commons

\section{Recommended Citation}

Sungjoon Cho, China - Measures Affecting Imports of Automobile Parts, (2008).

Available at: https://scholarship.kentlaw.iit.edu/fac_schol/169

This Brief is brought to you for free and open access by the Faculty Scholarship at Scholarly Commons @ IIT Chicago-Kent College of Law. It has been accepted for inclusion in All Faculty Scholarship by an authorized administrator of Scholarly Commons @ IIT Chicago-Kent College of Law. For more information, please contact jwenger@kentlaw.iit.edu, ebarney@kentlaw.iit.edu. 


\section{BEFORE THE APPELLATE BODY OF THE WORLD TRADE ORGANIZATION}

\section{CHINA - MEASURES AFFECTING IMPORTS OF AUTOMOBILE PARTS (WT/DS339/R;WT/DS340/R;WT/DS/342)}

\section{AMICUS CURIAE SUBMISSION BY SUNGJOON CHO}




\section{Introduction}

1. Recognizing the legal authority of the Appellate Body to accept and consider an unsolicited amicus curiae submission, ${ }^{1}$ I respectfully submit this brief through the Appellate Body Secretariat.

2. The gist of this dispute is whether the Chinese customs office should impose an import duty of 25 percent on certain auto parts having the essential character of motor vehicles while it levies only 10 percent on ordinary auto parts which do not retain such character. Generally, WTO members hold the "right" to interpret Harmonized System (HS) and this is why different members may have different interpretations in the same tariff classification issues, which was the case in this dispute. ${ }^{2}$ However, the panel ignored this right of importing countries and instead equated the object and purpose of the WTO Agreement with predictability and expectation exclusively for exporting countries, as it relates to "the substantial reduction of tariffs and other barriers to trade." 3 This is a flawed interpretation which severely undermines the balance of rights and obligations among WTO members and thus should be corrected by the Appellate Body.

\section{The Panel erred in applying the National Treatment discipline (GATT Article III:2) in a dispute involving custom duties (GATT Article II:1).}

\footnotetext{
${ }^{1}$ Appellate Body Report, United States - Imposition of Countervailing Duties on Certain HotRolled Lead and Bismuth Carbon Steel Products Originating in the United Kingdom, WT/DS138/AB/R, adopted 7 June 2000, paras. 39, 42; Appellate Body Report, European Communities - Trade Description of Sardines, WT/DS231/AB/R, adopted 23 October 2002, ๆๆ $157,160$.

2 The panel acknowledged this point. China - Measures Affecting Imports of Automobile Parts, the Report of the Panel, WT/DS339/R, WT/DS340/R, WT/DS342/R, circulated on July 18, 2008, I 7.538 [hereinafter the Panel Report].

3 Id., ๆ 7.460.
} 
3. What is before the Appellate Body is a typical "classification" dispute under Article II. It is worthy of noting that all import duties may be indeed "discriminatory" in the sense that they establish tariff barriers against otherwise free flow of foreign imports. However, to the extent that WTO members impose tariffs under their schedules those tariffs should be protected in the WTO system and thus are not subject to Article III. Negotiation, not adjudication, should reduce the level of these tariffs.

4. Even if these two Articles (Article II and III) arguendo rival each other in their application in this dispute, the panel should have elected to apply Article II. It is a well established interpretive principle of public international law that a tribunal must respect policy discretion of sovereign countries in times of doubt. The Appellate Body has also recognized this principle of in dubio mitius. 4 In this dispute, applying Article II definitely better suits the preserving of China's fiscal autonomy.

5. Concomitantly, the panel's "conditional" approach which led the panel to conclude that China violated both Articles II and III was flawed. It is simply illogical to conceive that the same measure could fall within the rubric of a border measure and at the same time of an internal measure. This type of reasoning, albeit conditional, is prone to severe unpredictability of the WTO jurisprudence,

\footnotetext{
4 Appellate Body Report, European Communities-Measures Concerning Meat and Meat Products (Hormones), ๆ165, n. 154, WT/DS26/AB/R (Jan. 16, 1998).
} 
in particular from a remedial perspective. The panel violated Article 3.2 of Dispute Settlement Understanding (DSU) since its approach neither "provid[ed] security and predictability to the multilateral trading system" nor "clarif[ied] the existing provisions of those agreements.” As the panel in Korea - Various Measures on Beef did,5 the panel in this dispute should have addressed Article II first and then declined to review the Article III claim exercising the judicial economy.

6. In its refusal to apply Article II in this dispute, the panel ran afoul of the interpretative principle under Article 31 of the Vienna Convention on the Law of Treaties. Article II:1 (b) reads:

The products described in Part I of the Schedule relating to any contracting party, which are the products of territories of other contracting parties, shall, on their importation into the territory to which the Schedule relates, and subject to the terms, conditions or qualifications set forth in that Schedule, be exempt from ordinary customs duties in excess of those set forth and provided therein. Such products shall also be exempt from all other duties or charges of any kind imposed on or in connection with the importation in excess of those imposed on the date of this Agreement or those directly and mandatorily required to be imposed thereafter by legislation in force in the importing territory on that date. (italics added)

7. The panel held that:

[W] consider that, taken together, the terms "on their [products] importation" and "into the territory" in the first sentence of Article II:1(b) suggest that "ordinary customs duties" are charges which the obligation to pay accrues based on the products as they enter the customs territory of another Member. In particular, the strict temporal element of the word "on", which points to the precise moment of the action it modifies,

${ }_{5}^{5}$ Korea- Measures Affecting Imports of Fresh, Chilled and Frozen Beef, the Report of Panel, 9780 , WS/DS169/R (July 31, 2000). 
indicates that an "ordinary customs duty" must be assessed on the basis of a good at the moment of importation. (italics added)

8. This is an unduly narrow reading of Article II:1 (B). The panel predicated its whole logic on a mechanical interpretation which employed only a couple of phrases under the Article in an exclusive manner. According to the panel, an ordinary custom duty must be always imposed precisely at the very moment of importation. However, it is an inorganic interpretation which totally ignores other important phrases modifying this temporal element, such as "subject to the terms, conditions or qualifications." The correct reading is that ordinary customs duties, which are usually imposed at the time of importation, may be imposed at a later stage. Interpreting the Article in this way, the Chinese customs office may impose on foreign auto parts an import duty of $25 \%$ after the Verification Center completes its assessment as to whether these parts meet the criteria of essential character as motor vehicles. ${ }^{6}$ In other words, such criteria represent the "terms, conditions or qualifications" under the Article and thus modify the temporal requirement in collecting tariffs ("on their importation into the territory").

9. Likewise, the panel's constricted reading which disassociates the phrase of "in connection from the importation" from ordinary custom duties is overly artificial. Such reading ignores the main message of Article II, which prohibits WTO members from imposing any customs duties exceeding their tariff schedules regardless of characterization ("ordinary" or "other") of such duties or their temporal dimension as long as they are import-related.

${ }^{6}$ The Panel Report, ๆ 7.67-7.69. 
10. The panel also failed to take into account the "General Rules of Interpretation" (GIR) under the Harmonized System as well as decisions of the HS Committee of the World Customs Organization (WCO) as a critical "context" as to Article II:1(b). The Appellate Body in EC - Chicken Cuts viewed that:

The Harmonized System is not, formally, part of the WTO Agreement, as it has not been incorporated, in whole or in part, into that Agreement. Nevertheless, the concept of "context", under Article 31, is not limited to the treaty text-namely, the WTO Agreement-but may also extend to "any agreement relating to the treaty which was made between all the parties in connection with the conclusion of the treaty", within the meaning of Article 31(2)(a) of the Vienna Convention, and to "any instrument which was made by one or more parties in connection with the conclusion of the treaty and accepted by the other parties as an instrument related to the treaty", within the meaning of Article 31(2)(b) of the Vienna Convention. Moreover, should the criteria in Article 31(3)(c) be fulfilled, the Harmonized System may qualify as a "relevant rule[] of international law applicable in the relations between the parties".

11. GIR 2(a) provides:

Any reference in a heading to an article shall be taken to include a reference to that article incomplete or unfinished, provided that, as presented, the incomplete or unfinished article has the essential character of the complete or finished article. It shall also be taken to include a reference to that article complete or finished (or falling to be classified as complete or finished by virtue of this rule), presented unassembled or disassembled. (emphasis added)

12. GIR 2(a) tends to inform the Chinese measures in question. Imported auto parts are "incomplete or unfinished" articles which may have the "essential character" of complete or finished ones and thus be subject to a tariff rate (25\%) corresponding to complete or finished ones (motor vehicles). Again, the panel narrowly interpreted GIR 2(a), in particular the phrase of "as presented," and concluded that it "denotes a temporal meaning, i.e. the moment when a good is 
presented to the customs authority."7 According to the panel's reading, China may not predicate its measures on GIR 2(a) since these measures apply to auto parts imported through "multiple shipments" and therefore cannot satisfy the "as presented" requirement.

13. However, as the panel itself noted, the "determination whether multiplicity of origin shall affect applicability of GIR 2(a) is a matter left to each Contracting Party." More precisely, the HS Committee decided that "the classification of goods assembled from elements originating in or arriving from different countries are matters to be settled by each country in accordance with its own national regulations." Therefore, it is obvious that the China enjoys wide discretion in classifying auto parts having the essential character of motor vehicles as motor vehicles. The opposite conclusion reached by the panel is an unacceptable second-guessing which ignores the context of GATT Article II:1(b) and thus runs afoul of Article 31 of the Vienna Convention on the Law of Treaties.

14. Finally, in its consideration of the "object and purpose" of the WTO Agreement, the panel disproportionately accentuated the complainants (exporting countries)' concerns through GATT Article III:2 and therefore undermined the defendant (importing country)'s expectation embedded in Article II:1(b). The panel held that:

[T] he "security and predictability of the reciprocal and mutually advantageous arrangements directed to the substantial reduction of tariffs

7 Id., 97.412

${ }^{8} I d, 97.432$ 
and other barriers to trade ", which is a recognized object and purpose of the WTO Agreement, would be undermined if a charge were to be considered as an ordinary customs duty even when the obligation to pay the charge accrues after goods have already entered into the customs territory of China and been assembled into complete goods of the corresponding kind. We therefore share the systemic concerns expressed by the complainants that if the assembly of the products after their importation into the customs territory of a Member could provide a basis for tariff classification, the tariff classification system would undermine the national treatment obligation under Article III of the GATT 1994, which is one of the core principles of the WTO Agreements. Such an interpretation would blur the fundamental distinction between measures falling within the scope of Article III:2 and those falling within the scope of Article II:1(b), first sentence, of the GATT $1994 .{ }^{9}$

15. This biased understanding of the WTO's object and purpose has no place in the WTO's jurisprudence. The Appellate Body in the EC-Computer Equipment ruled that:

[W]e disagree with the Panel that the maintenance of the security and predictability of tariff concessions allows the interpretation of a concession in the light of the "legitimate expectations" of exporting Members, i.e., their subjective views as to what the agreement reached during tariff negotiations was. The security and predictability of tariff concessions would be seriously undermined if the concessions in Members' Schedules were to be interpreted on the basis of the subjective views of certain exporting Members alone. ${ }^{10}$

16. In sum, the panel's interpretation of GATT Article II:1 was inconsistent with Article 31:1 of the Vienna Convention on the Law of Treaties because the panel misread the text of Article II:1, disregarded its critical context (the GIR 2(a) and the HS Committee's decision), and misconstrued the object and purpose of the WTO Agreement.

\footnotetext{
9 Id., ๆ 7.211

${ }^{10}$ European Communities - Customs Classification of Certain Computer Equipment, WT/DS62/AB/R; WT/DS67/AB/R; WT/DS68/AB/R, the Appellate Body Report, ๆ 82 (June 5, 1998).
} 


\section{In its conditional interpretation of Article II:1, the panel wrongly disregarded importing countries' discretion in the tariff classification under the "multiple shipment" situation.}

17. As discussed above, the gist of the Chinese measures in question is China's treatment of certain auto parts as motor vehicles for the purpose of tariff classification if the former have the essential character of the latter under China's internal criteria. The existence of GIR 2(a) as an important context to GATT Article II:1 tends to justify these measures.

18. However, the panel refused to accept this position by narrowly interpreting GIR 2(a) in a way which unduly ignored an importing country's discretion in tariff classification. According to the panel, the language "as presented" in GIR 2(a) presupposes only the "single shipments" scenario in the importation of auto parts and therefore precludes the "multiple shipments" scenarios on which the Chinese measures are based.11

19. As the panel noted itself, the HS Committee's decisions function as critical guidance in interpreting both GATT Article II:1 and WTO members' tariff schedules, as was confirmed by the Appellate Body in EC-Compute Equipment and EC-Chicken Cuts. ${ }^{12}$ The HS Committee had concluded earlier that each importing country should determine whether it would treat split consignments as a single entity in interpreting "as presented" under GIR 2(a).13 In particular, the HS Committee decided in 1995 that "the questions of split consignments and the

11 Panel Report, I 7.523.

${ }^{12}$ Id., 97.423 .

13 Id., ๆๆ 7.408-409. 
classification of goods assembled from elements originating in or arriving from different countries are matters to be settled by each country in accordance with its own national regulations." 14

20. The same discretion of the importing countries is secured in constructing the "essential character" requirement in GIR 2(a). As the panel acknowledged, the WCO Secretariat has noted that "the Nomenclature and Explanatory Notes are largely silent regarding the meaning of the "essential character" of the complete or finished article as it appears in GIR 2(a)" and that "the Committee has not formally developed principles, nor has the Committee ruled formally on the classification of unassembled sets of parts for motor vehicles of Chapter 87."15 In other words, "absent specific guidance from the nomenclature (i.e. legal provisions) or the Committee (i.e. interpretation of the nomenclature), it is within the purview of national customs administrations to interpret provisions such as GIR 2(a)."16

21. The HS Committee's recognition of importing countries' wide discretion in the matter of tariff classification undoubtedly supports an interpretation of "as presented" in a way which accommodates the aforementioned "multiple shipments" scenario or "the classification of goods assembled from elements originating in or arriving from different countries." 17 Therefore, certain incomplete or unfinished auto parts having the "essential character" of motor

${ }_{14}$ Id., ๆ 7.425; HSC/16/Nov.95, DOC.39.600.

15 Panel Report, I 7.529.

${ }^{16}$ Id., 97.531.

${ }^{17}$ Id., 97.397. 
vehicles may be classified as motor vehicles at the discretion of importing countries in a way consistent with GATT Article II:1.

22. It is truly unfathomable that the panel defied such unequivocal interpretive guidance. The panel viewed that treating unassembled parts (such as auto parts) as assembled articles (such as motor vehicles) under GIR 2(a) must be limited to "technological" reasons such as difficulties in packaging and handling. ${ }^{18}$ According to the panel, GIR 2(a) does not address the measures in question since the tariff classification under the measures represents "industrial," not merely technological, consideration. ${ }^{19}$ However, the panel's view is groundless for the following reasons.

23. First, surprisingly the panel based its whole logic for the above-mentioned position on a four-decades-old document under the Customs Cooperation Council (CCC), which was the WCO's predecessor. According to the legislative history of GIR 2(a) noted by the CCC Secretariat in 1963, the tariff nomenclature was originally designed for technological classification of different articles. ${ }^{20}$ Yet this is merely a "historical background" of draft interpretive rules, as the WCO Secretariat reaffirmed in its letter to the panel dated on July 30, 2007. The WCO Secretariat emphasized that the text of the Explanatory Note (V) to GIR 2(a), which reflects the CCC Secretariat's historical observation, is "merely an explanation of historical reasons for articles being shipped unassembled or

${ }^{18}$ Id., 97.439

$19 \mathrm{Id}$.

${ }^{20}$ Id., I 7.439; Customs Co-operation Council, Nomenclature Committee, $10^{\text {th }}$ Session, Brussels, February 26, 1963, Document No. 10.195E. 
disassembled." ${ }^{21}$ While it is true such historical background may provide certain guidance in the panel's interpretation of the current text of GIR 2(a), it is still a type of "supplemental" interpretive means as "preparatory work" of the text of GIR 2(a) under Article 32 of the Vienna Convention on the Law of Treaties. It can by no means surpass more direct interpretive means such as the HS Committee's decision in 1995 as a "subsequent practice" under Article 31:3 of the Vienna Convention on the Law of Treaties.

24. Second, even if we accept arguendo the historical explanation highlighting a technological dimension of the tariff nomenclature as the sole interpretive guidance for GIR 2(a), it does not necessarily preclude other non-technological considerations of importing countries. As the panel itself acknowledged, the Explanatory Note (V) to GIR 2(a) provides that "when the goods are presented unassembled or disassembled, it is usually for reasons such as "requirements or convenience of packing, handling or transport."”22 This means that importing countries may accommodate non-technological reasons such as the imposing of different custom duties under certain circumstances, as was in this dispute. Moreover, even if Paragraph 10 of the HS Committee decision in 1995 does not refer to the multiple shipment situation in this dispute as the panel observed, ${ }^{23}$ the same Paragraph never actually bars the multiple shipment scenarios either. In fact, the panel explicitly recognized this very point. The panel viewed that: The WCO Secretariat states that it is inclined to regard the reference in paragraph 10 to "the classification of goods assembled from elements

\footnotetext{
${ }^{21}$ Panel Report, ๆ 7.441, n. 747 (emphasis added).

22 Panel Report, \ 7.441

$23 \mathrm{Id}$.
} 
originating in or arriving from multiple countries" rather as reflecting the HS Committee's view that the determination whether "multiplicity of origin" shall affect the applicability of GIR 2(a) is a matter left to each Contracting Party and that the HS does not address the applicability of GIR 2(a) to the classification of goods of mixed origin. ${ }^{24}$

If the WTO members had truly desired to bar any non-technological considerations in the matter of tariff classification, they would have stipulated explicitly, as was the case in the area of the rules of origin. ${ }^{25}$

25. Third, the very distinction between "technological" considerations and nontechnical ("economic") considerations in the tariff classification is not always clear cut. All tariff nomenclature issues may be economic in the sense that they are all to impose custom duties after all. As the panel itself observed, "classification of a good into the proper tariff heading is an essential first step for assessing the appropriate tariff duty on the product." ${ }^{26}$ Simply speaking, the panel must leave to importing countries the question of whether these nontechnological considerations should be included in the tariff classification. It is not for the panel to decide.

26. In sum, the panel erred in that it misinterpreted GIR 2(a) in a way which would unduly undermine importing countries' discretion as to their tariff classification under the multiple shipment situation as in this dispute.

\footnotetext{
24 Id., I 7.442.

25 "Until the work programme for the harmonization of rules of origin set out in Part IV is completed, Members shall ensure that: [...] (b) notwithstanding the measure or instrument of commercial policy to which they are linked, their rules of origin are not used as instruments to pursue trade objectives directly or indirectly[.]" (emphasis added)

${ }^{26}$ Panel Report, I 7.449.
} 


\section{Conclusion}

27. For the abovementioned reasons, the panel's interpretation breached general and supplemental rules of interpretation under Articles 31 and 32 of the Vienna Convention on the Law of Treaties. This is hardly "an objective assessment of the matter before it" and thus the panel failed to discharge its functions under Article 11 of the DSU. In doing so, the panel undermined the delicate balance of rights and obligations among WTO members. The Appellate Body should correct such flaw and restore the WTO jurisprudence in this matter. 